Ann. Biol. anim. Bioch. Biophys., I976, 16 (3), 319-325.

\title{
5 $\alpha$-ANDROSTANEDIOLS DURING SEXUAL MATURATION : BIOSYNTHESIS BY THE IMMATURE RAT OVARY IN VITRO AND SOME BIOLOGICAL EFFECTS
}

\author{
B. ECKSTEIN \\ Department of Zoology, \\ Hebrew University of Jerusalem, \\ Jerusalem (Israel)
}

\section{SUMMARY}

It seems that the concept of differential sensitivity (with estradiol as the peripheral steroid) cannot explain the onset of puberty in the female rat. The peripuberal shift in negative feedback sensitivity has been amply demonstrated, but this does not prove that these differences are responsible for sexual maturation (DAvidson, I974). Estrogens have not been found in the circulation of peripuberal rats and the injection of small doses of estradiol to Wistar rats is ineffective in inducing precocious puberty.

The immature rat ovary produces $5 \alpha$-androstane- $3 \alpha-x ; \beta$-diol $(3 \alpha-\mathrm{A})$ and its $3 \beta$-epimer $(3 \beta-\mathrm{A})$ that are present in blood in concentrations of $100 \mathrm{ng} / \mathrm{ml}$ and more; they disappear after onset of puberty. These steroids exert a negative feedback on $\mathrm{LH}$ release (the $3 \alpha-A$ ), induce precocious vaginal opening (the $3 \beta-A$ ), and can induce precocious ovulation when injected in a proper dose (the $3 \beta-A)$. Therefore, it seems that these steroids participate in the regulation of puberty in the female rat.

It is still premature to speculate on a specific way by which puberty is initiated.

During infancy, as in the adult, sex steroids from the gonads inhibit gonadotropin secretion via the brain. Since less steroid is required to inhibit gonadotropin secretion in young individuals than in adults, it was implied that neural receptors are more sensitive to the negative feedback action of sex steroids in young than in adult individuals. Therefore, the fundamental change in the advance toward sexual maturity would seem to be a reduction of the sensitivity of the hypothalamus toward gonadal steroids, or in other words, an increase in the threshold of the inhibitory (negative) feedback receptors which respond to changes in circulating steroid levels by inducing reciprocal changes in gonadotropin output. As a result, a transitory release from inhibition occurs, leading to increased gonadotropin secretion. A higher gonadotropin level induces a reciprocal increase in the circulating steroid 
level. Consequently, both, gonadotropin as well as steroid secretion are at an elevated level at which they achieve a new "steady state " of feedback inhibition; this is the adult level at which the development of secondary sexual characteristics is stimulated and cyclic activity begins (see reviews of DONOVAN and VAN DER WERFF TEN BOSCH, I965; CRITCHLOW and BAR-SELA, I967). This explanation known as the concept of differential sensitivity, is based on experiments with castrated rats in which a higher sensitivity of immature animals to estrogen administration in suppressing $\mathrm{LH}$ release was noted. The peripuberal shift in negative feedback sensitivity has recently been confirmed using castrated rats infused (STEELE and WEISZ, 1974) or injected (EIDRIDGE et al., I974) with estradiol.

Since the concept is based solely on a quantitative change (increase) of estrogen and gonadotropin in peripheral circulation, it can be evaluated by precise measurements of these hormones in the blood. Although, the increase in estrogen concentration necessary to inhibit gonadotropin secretion at puberty could be very low, a decreased level at puberty is difficult to reconcile with the concept. In a recent study plasma estradiol-I $7 \beta$ was estimated using a radioimmunoassay (RIA) highly specific for this steroid. The values measured with this system in adult rats ranged from means of $1.75 \mathrm{pg} / \mathrm{ml}$ at metestrus, to $33 . \mathrm{I} \mathrm{pg} / \mathrm{ml}$ at proestrus. Maximal concentrations of 55 to $60 \mathrm{pg} / \mathrm{ml}$ were found at IO- 15 days of age, while from day 25 to 35 no estradiol could be detected (MEIJS-ROELOFs et al., I973). Similar results for estrone were obtained by WEISz and Gunsalus (r973).

Careful measurements of serum gonadotropins in prepuberal rats by RIA were performed in several laboratories (DÖHLER and WUTTKE, I974; WEISZ and FERIN, I970, and others). In most laboratories it was found that serum $\mathrm{L}_{\mathbf{H}} \mathrm{H}$ and $\mathrm{FSH}$ remained low from weaning up to the immediate period of puberty, in female rats, while others, as OJEDA and RAMIREZ (I972) found a significant rise in $\mathrm{LH}$ before the onset of puberty.

The lack in increased estradiol level in the peripuberal rat and the large discrepancy in basal $\mathrm{L}_{\mathrm{H}} \mathrm{H}$ values is hard to reconcile with the concept of differential sensitivity, assuming estradiol as the peripheral steroid.

\section{CHANGES IN PRODUCTION OF STEROIDS AT PUBERTY}

From diverse observations it became apparent that a qualitative change in steroidogenesis occurs in the gonads around the time of the onset of puberty, as postulated long ago by VAN DER WERFF TEN BOSCH (I964). In the male, such changes have been amply demonstrated (LINDNER and MANN, 1960; LINDNER, I96I ; BAILIE and GRIFFITHS, I964). There are indications that a change in steroid conversion occurs also in the ovary. DONOVAN and O'KEEFFE (I 966) on the basis of experiments in which they showed a difference in the function of the liver to inactivate estradiol postulated that the ovary produces different steroids before puberty than in the adult. The effect of exogenous estrogens on the secretion of pituitary gonadotropins in the immature rat is dependant on the concurent secretion of ovarian hormones. BRADBURY (1947) was the first to report that estrogen injections to 26-dayold rats stimulated a loss of pituitary gonadotropic potency that was associated with 
secretion, and that this response could be blocked by ovariectomy at the time of the initial injection. This was subsequently confirmed by both, LH (RAMrREZ and SAWYER, 1965) and FSH (CoRBin and DANIELS, I969)

\section{PRODUCTION IN VIVO AND IN VITRO}

\section{OF ANDROSTANEDIOLS BY THE IMMATURE RAT OVARY}

In looking for a change in steroid metabolism associated with puberty, we incubated ovaries of rats at the age of 34 days with ${ }^{3} \mathrm{H}$-pregnenolone in the presence of a NADPH generating system. Most of the radioactivity was recovered in one peak, the major portion of which was subsequently identified as $5 \alpha$-androstane- $3 \alpha, \mathrm{I} 7 \beta$ diol $(3 \alpha-\mathrm{A})$. Ovaries of 40 -day-old rats incubated with ${ }^{3} \mathrm{H}$-pregnenolone at the same procedure did not produce this steroid (EcKSTEIN et al., I970), nor was it known to appear in incubations of mature rat ovaries (RICE and SEGALOFF, I966; SAWARD and CASEY, 1964). The $3 \alpha-\mathrm{A}$ as well as its $3 \beta$-epimer $(3 \beta-\mathrm{A})$ were shown to be present in peripheral blood of immature female rats in concentrations of $100 \mathrm{ng} / \mathrm{ml}$ and more, but were undetectable in cycling rats (ECKSTEIN and RAvID, 1974). The source of the androstanediols present in the blood seems to be ovarian, since ovariectomy at the age of 19 days resulted in the disappearance of both steroids from the circulation at the age of 23 days, while the level of both compounds in sham operated animals measured at the same time remained high (ECKSTEIN, r974).

\section{BIOSYNTHETIC PATHWAY FOR THE PRODUCTION OF $3 \alpha-A$}

Recently Yamada and Matsumoto (I974) showed that $5 \alpha$-reduced $\mathrm{C}_{19}$ steroids in the immature rat testis are formed mainly from progesterone via a $5 \alpha$-reduced I $7 \alpha$-hydroxypregnane, and that very little $5 \alpha$-reduced metabolites are produced in adult testes from progesterone. Thus, the $5 \alpha$-reduced pathway for progesterone metabolism seems to be active in the male rat only until the onset of puberty.

It was of interest to see whether the production of the androstanediols in the ovary is accomplished by a similar pathway. Incubation of the $I$ ooo $\times \mathrm{g}$ supernatant from 23 -day-old ovarian homogenate with ${ }^{14} \mathrm{C}$-progesterone resulted in the production of 3 major metabolites : $3 \alpha-\mathrm{A}$, and two $5 \alpha$-reduced pregnanes that were identified as $3 \alpha$-hydroxy-5 $\alpha$-pregnan-20-one and $3 \alpha, 17 \alpha$-dihydroxy-5 $\alpha$-pregnan-20-one. The $3 \alpha, I 7 \alpha$-dihydroxy compound has not hitherto been isolated from any ovarian tissue. The identification of these compounds as the major conversion products of progesterone suggested that $5 \alpha$-androstanediol may be produced in the immature rat ovary from the two identified $5 \alpha$-reduced pregnanes as intermediates. To verify this assumption, ovaries of rats at the age of 23 days were homogenized and the $\mathrm{I} 000 \times \mathrm{g}$ supernatant incubated with $3 \alpha$-hydroxy- $5 \alpha$-pregnan-20-one as substrate. A linear relationship was found between the time of incubation and the quantity of $3 \alpha-\mathrm{A}$ produced. Thus, a pathway leading from progesterone to $3 \alpha-A$ through $5 \alpha$-reduced pregnanes was found to operate in the immature rat ovary (LERNER and ECKSTEIN, I976). 
Production and metabolism of progesterone in mature rat ovarian tissue has been studied in several laboratories. It appears that under in vitro and in vivo conditions, the two steroids, progesterone and 20x-hydroxy-pregn-4-en-3-one are the predominant products formed at all times during the normal reproductive life. ICHIKAWA et al. (I974) determining steroids in ovarian venous effluent of proestrous rats found too, that the delta-3,4-ketosteroids are the predominant secretory products of the mature ovary.

In contrast to these findings with mature ovarian tissue, our results demonstrate that the immature rat ovary converts progesterone mainly to $5 x$-reduced steroids. Thus, the steroidogenic potential of the immature rat ovary differs considerably from that of the mature gonad. While in the immature gonad the pathway leading to $5 \alpha$-A through the $5 \alpha$-pregnanes is predominant, in the mature gonad, at least during proestrus, the delta-4,3-ketosteroids and pathways leading to estrogen formation are prefered.

The mechanism by which the change in progesterone metabolism at the time of sexual maturation is induced remains obscure. INANo et al. (I966) have shown that at the time of puberty in the male rat the activity of the $5 \alpha$-reductase sharply declines, while the activity of the $I 7 \beta$-hydroxysteroid dehydrogenase increases. Such a shift has not been sought for in the female rat. In neither males nor females is the signal that initiates the profound changes in steroidogenesis known.

\section{BIOLOGICAL EFFECTS OF THE ANDROSTANEDIOLS}

From the above observations it is evident that there occurs a profound change in the capacity of the ovary to perform metabolic conversion of steroids at puberty. The main product of their steroidogenetic activity before puberty are the androstanediols. It was therefore of interest to see whether these steroids can substitute for the biological effects ascribed till now to estradiol-I $7 \beta$, namely ; $a$ ) Inhibition of L,H release, $b$ ) Vaginal opening and $c$ ) Precocious ovulation.

\section{Effect of androstanediols in suppressing postcastrational LH release}

Rats ovariectomized at the age of 20 days were injected daily from the 2 Ist to the 5 oth day of age either with $3 \alpha$-A or $3 \beta$-A or estradiol benzoate (Eckstein et al., in preparation). Blood was drawn (at 8 to Io $\mathrm{AM}$ ) every $5^{\text {th }}$ day throughout the experimental period, for LH determination by RIA. All the 3 concentrations of $3 \alpha-A$ tested $\left(25,5^{0}\right.$ and Ioo $\mu \mathrm{g} / \mathrm{IOO} \mathrm{g} /$ day) effectively suppressed. $\mathrm{L} / \mathrm{H}$ release, while the same concentrations of $3 \beta-A$ were completely ineffective in this respect.

\section{Vaginal opening}

The time of sexual maturation in the female rat is sometimes estimated by this parameter. In our local strain of rats, Wistar descendants as well as in other strains, vaginal opening in the majority of rats is neither accompanied by a fully cornified 
smear, nor by ovulation. Only when vaginal opening occurs after the 4oth day of age, is it in most instances accompanied by the first ovulation. Furthermore, the mechanism responsible for vaginal opening is still unknown, as demonstrated by table I

TABLE I

Effect of ovariectomy and adrenalectomy on vaginal opening in rats

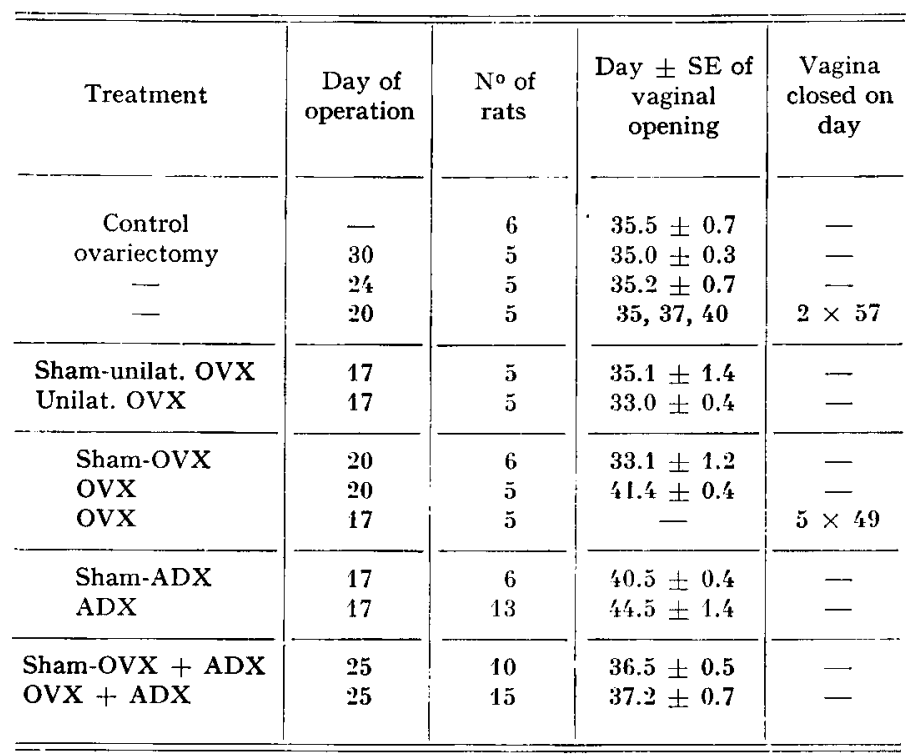

Although vaginal opening by itself is no indication for the onset of puberty, it is nevertheless a prerequisite for it. Administration of $3 \beta-\mathrm{A}$ in 3 daily doses of roo $\mu \mathrm{g} /$ rat, begining at the age of 20 days, advanced considerably vaginal opening, as seen in table 2 . This effect of $3 \beta-A$ is mediated by the ovaries, since it is abolished by ovariectomy.

TABLE 2

Effect of $100 \mu \mathrm{g} 3 \beta-A$ (disolved in $0.2 \mathrm{ml}$ sesame oil) injected on days 20,21 and 22, on the day of vaginal opening in rats

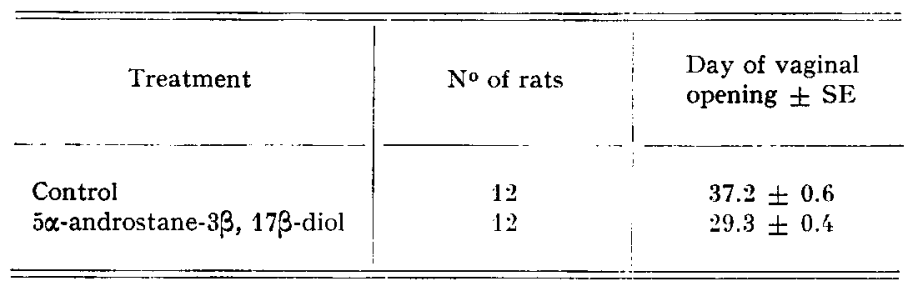




\section{Precocious ovulation}

Daily treatment with $25 \mu \mathrm{g}$ of $3 \beta$-A from day $2 \mathrm{I} \mu \mathrm{p}$ to vaginal opening advanced the first ovulation, whereas a daily dose of 100 to $400 \mu \mathrm{g}$ induced precocious vaginal opening but delayed the first ovulation, probably by inhibiting gonadotropin release (ECKSTEIN, I975). RAMIREZ and SAwYER (I965) were the first to demonstrate that small doses of estradiol injected daily to Spraque-Dawley rats from day 26 until vaginal opening advanced the first ovulation.

Unfortunately, this effect could not be repeated using Wistar derived rats (DÖckE and IORNER, I974, as well as our own results).

Sexual Maturation 3rd Workshop
August 31. September 3, 1975.

\section{RÉSUMÉ}

\section{5x-ANDROSTANEDIOLS PENDANT LA MATURATION SEXUEL,LE : BIOSYNTHÈSE IN VITRO PAR L'OVAIRE DE RATTE IMMATURE ET EFFETS BIOLOGIQUES}

Le concept de sensibilité différentielle (avec l'estradiol comme stéroïde périphérique) ne peut expliquer l'apparition de la puberté chez la Ratte.

Le changement de sensibilité de la rétroaction négative qui se produit au moment de la puberté a été amplement démontré, mais cela ne prouve pas que ce changement est responsable de la maturation sexuelle (Davidson, 1974). On ne trouve pas d'estrogènes dans la circulation juste avant la puberté, et l'injection de petites doses d'estradiol à des Rattes Wistar est inefficace pour induire une puberté précoce.

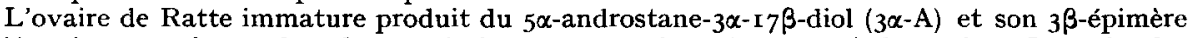
(3ß-A) qui sont présents dans le sang à des concentrations de Ioo $\mathrm{ng} / \mathrm{ml}$ et plus. Ces stéroïdes disparaissent après la puberté.

La $3 \alpha-A$ exerce un rétrocontrôle négatif sur la sécrétion de $\mathbf{L H}$, le $3 \beta-\mathrm{A}$ induit une ouverture vaginale précoce et peut provoquer une ovulation précoce quand on l'injecte à une dose convenable. Ces deux stéroïdes semblent donc participer à la régulation de la puberté chez la Ratte. Il est prématuré de faire des hypothèses sur un mécanisme spécifique initiateur de la puberté.

\section{REFERENCES}

BaILLIE A. H., GRIFFITHS K., I964. 33-hydroxysteroid dehydrogenase activity in the mouse Leydig cell. J. Endocr., 29, 9-17.

Bradbury J. T., 1947. Ovarian influence on the response of the anterior pituitary to estrogens. Endocrinology, 41, 501-513.

Corbin A., Daxiels E. L., I969. Induction of puberty in immature female rats : Effects of estrogen on pituitary $\mathrm{F} 3 \mathrm{H}$ and stalk-median-eminence FSH-releasing factor. Neuroendocrinology, 4, 65-74.

Critchlow V., Bar-Sela M. E., I967. Control of onset of puberty, Ioi-I62, in : Martini L., Ganong W. F., Neuroendocrinology, Vol. 2, Academic Press, New York, London.

Davidson J. M., I974. Hypothalamic-pituitary regulation of puberty, evidence from animal experimentation, pp. 79-I03, in : GRUMBACH M. M., GRAVE G. D., MAYER F. E., The Control of the onset of puberty, J. Wiley and Sons, Inc.

1)̈̈cke F., Dörxer G., 1974. Estrogen and gonadotropin secretion in the immature rat. J. Endocr., $63,285-298$. 
Döhler K. D., WUtTke W., I974. Serum LH, FSH, prolactin and progesterone from birth to puberty in female and male rats. Endocrinology, 94, 1003-1008.

Donovan B. T., O'Keeffe M. C., 1966. The liver and the feedback action of ovarian hormones in the immature rat. $J$. Endocr., 84, 469-478.

Donovan B. T., Van der WerfF ten Bosch J. J., 1965. Physiology of puberty, Williams and Wilkins, Baltimore.

Eckstein B., 1974. The origin of $5 \alpha$-androstane- $3 \alpha$, $17 \beta$-diol and its $3 \beta$-epimer in peripheral blood of immature female rats. $J$. Steroid Biochem., 5, 577-580.

Eckstein B., I975. Studies on the mechanism of the onset of puberty in the female rat. J. Steroid Biochem., 6 (in press).

Eckstein B., Mechoulam R., Burstein S. H., I97o. Identification of $5 \alpha$-androstane-3 $\alpha$, $17 \beta$-diol as a principle metabolite of pregnenolone in rat ovary at the onset of puberty. Nature, London, 228 , 866-868.

Eckstein B., RAvid R., 1974. On the mechanism of the onset of puberty : Identification and pattern of $5 \alpha$-androstane- $3 \beta, 17 \beta$-diol and its $3 \alpha$-epimer in peripheral blood of immature female rats. Endocrinology, 94, 224-229.

Eldridge J. C., McPherson III, J. C., Mahesh V. B., I974. Maturation of the negative feedback control of gonadotropin secretion in the female rat. Endocrinology, 94, $1536-1540$.

Ichikawa S., SaWada T., Nakamura Y., Morioka H., I974. Ovarian secretion of pregnane compounds during the estrous cycle and pregnancy in rats. Endocrinology, 94, 1615-1620.

InANo H., HoRI Y., TAMAOKI B. I., I 966 . Effect of age on testicular enzymes related to steroid bioconversion. Ciba Found. Colloquia on Endocr., The testis, 16, 105-117.

Lerner N., Eckstein B., 1976. Identification of two $5 \alpha$-reduced pregnanes as major metabolites of progesterone in immature rat ovaries ( $\mathrm{I}$ ooo $\times \mathrm{g}$ supernatant) in vitro. Endocrinology (in press).

Lindner H. R., I96r. Androgens and related compounds in the spermatic vein blood of domestic animals. I. Neutral steroids secreted by the bull testis. J. Endocr., 23, 139-159.

Lindner H. R., MANN T., I960. Relationship between the content of androgenic steroids in the testes and the secretory activity of the seminal vesicles in the bull. J. Endocr., 21, 34I-360.

Meijs-Roelofs H. M. A., Uilenbroek J. Th. J., de Jong F. H., Welschen R., i973. Plasma oestradiol-17 $\beta$ and its relationship to serum FSH in immature female rats. $J$. Endocr., 59, 295-304.

OJeda S. R., Ramirez V. D., I972. Plasma level of LH and FSH in maturing rats : response to hemigonadectomy. Endocrinology, 90, 466-472.

Ramirez V. D., SAWYER Ch. H., 1965. Advancement of puberty in the female rat by estrogen. Endocrinology, 76, I I 58 - I 168 .

Rice B. F., Segaloff A., 1966. III. Estrogen biosynthesis from acetate-I-C ${ }^{14}$. Steroids, 7, $367-37$.

Saward K., CASeY P. Y., I964. Effect of pituitary hormones and NADPH on acetate utilization in ovarian and adrenocortical tissue. Endocrinology, 74, 599-60.

Steele R. E., Weisz J., I974. Changes in sensitivity of the estradiol LH feedback system with puberty in the female rat. Endocrinology, 95, 513-520.

VAN der Werff Ten Bosch J. J., I964. Control of puberty by endocrine and other factors. Proc. 2nd Internat. Congr. Endocr., II, London, 833-846.

WeIsz J., Ferin M., 1970. Pituitary gonadotropins and circulating LH in immature rats, a comparison between normal females and males and females treated with testosterone in neonatal life, 339-350. In, Butr W. R., Crooke A. C., Ryle M., Gonadotropins and ovarian development. Edinburgh : E. and S. Livingstone.

Weisz J., Gunsalus P., 1973. Estrogen levels in immature female rats : True or spurious, ovarian or adrenal? Endocrinology, 83, 1057-1065.

Yamada M., Matsumoto K., I974. Pathway from progesterone to $5 \alpha$-reduced $\mathrm{C}_{18}$ steroids. Endocrinology, 94, 777-784. 